\title{
PERKEMBANGAN KEMAMPUAN ASPEK KOGNITIF PESERTA DIDIK DALAM PROSES PEMBELAJARAN
}

\section{Ibrahim Ismail}

\begin{abstract}
Cognitive development is one of students' development aspects related to knowledge. It inlcudes all psychological processes related to individual's method to learn and comprehend his environment. Cognitive development is a development step of human from child to adult, from concrete thinking process to the advanced ones, which is abstract and covering logical concepts.

Cognitive development in children is their abilities to think in a more complicated way, do reasoning, and solve problems that include into psychological process related to an individual's method of learning and taking his environment into account. The characteristics of students' cognitive development have to be realized by all parties. With the comprehension of the characteristics of students' cognitive development, teachers and parents can determine the development limit the students had according to their age, so teachers and parents can implement the knowledge that suits children's cognitive skill.
\end{abstract}

\section{Keywords: Development of Students' Cognitive Skill}

\section{PENDAHULUAN}

Dalam perkembangannya, pendidikan berarti usaha yang dijalani oleh seseorang atau sekelompok orang untuk memepengaruhi seseorang atau sekelompok orang agar menjadi dewasa atau mencapai tingkat hidup ada penghidupan yang lebih tinggi dalam arti mental. ${ }^{1}$ Pendidikan merupakan suatu hal yang sangat penting yang tidak dapat dipisahkan dari kehidupan manusia karena pada dasarnya pendidikan tidak terlepas dari tugas manusia yang memiliki potensi untuk dididik dan terdidik. Pendidikan tidak terlepas dari tugas manusia untuk menumbuh dan mengembangkan usaha-usaha pembawaan baik

${ }^{1}$ Oyan D. Taufik K. dan Hairuddin Cikka, Penerapan Pendidikan Dasar Militer (Diksarmil) dalam Membentuk Kepribadian Resimen Mahasiswa Institut Agama Islam Negeri (IAIN) Palu, Moderasi: Jurnal Studi Ilmu Pengetahuan Sosial, Volume 1, No. 1, 120 
jasmani maupun rohani khususnya dalam pendidikan Islam. Usaha-usaha tersebut dilakukan untuk menanamkan nilai-nilai agama pada manusia dan norma-norma serta mewariskannya kepada generasi berikutnya yang akan dikembangkan dalam hidup dan kehidupan yang tidak terlepas daripada pendidikan yang diaplikasikan pada proses pembelajaran.

Belajar dan mengajar merupakan dua konsep yang tidak bisa dipisahkan antara satu dari yang lain, dimana dalam proses pembelajaran peserta didik dipandang sebagai subjek yang menerima pelajaran (sasaran didik), sedangkan mengajar menunjukkan pada apa yang harus dilakukan oleh guru sebagai pendidik.

\section{PEMBAHASAN}

\section{A. Perkembangan Kognitif}

\section{Pengertian Perkembangan kognitif}

Perkembangan kognitif adalah salah satu aspek perkembangan peserta didik yang berkaitan dengan pengetahuan, yaitu semua proses psikologis yang berkaitan dengan bagaimana individu mempelajari dan memikirkan lingkungannya. ${ }^{2}$

perkembangan kognitif adalah tahap-tahap perkembangan manusia mulai dari usia anak-anak sampai dewasa, mulai dari proses berfikir secara konkret sampai dengan yang lebih tinggi yaitu konsep-konsep abstrak dan logis. ${ }^{3}$

Perkembangan kognitif merupakan perubahan kemampuan berfikir atau intelektual. ${ }^{4}$ Bayak ulam islam membagi perkembangan kognitif berdasarkan empat priode, yang tedapat dalam QS Al-Ruum: 54 yang artinya

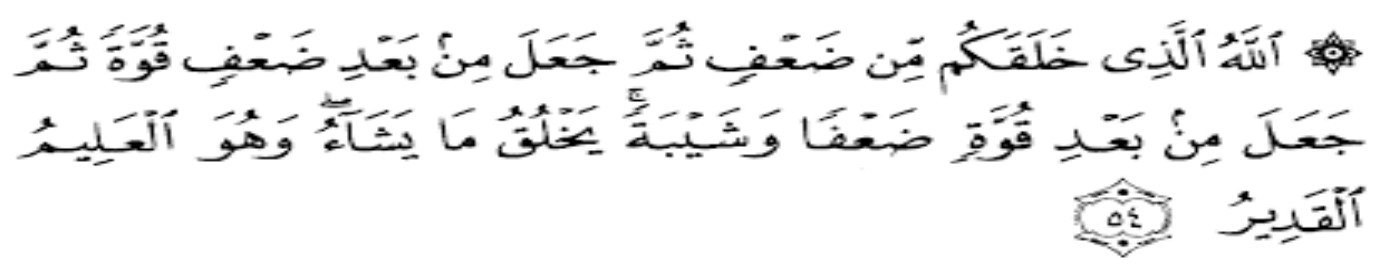

\footnotetext{
2009), 97

${ }^{2}$ Desmita, Psikologi Perkembangan Peserta Didik (Batu sangkar:PT Remaja Rosdakarya, ${ }^{3}$ http://teni-setiani.blogspot.com/2010/06/teori-perkembangan-kognitif.html, Diakses 8 Agustus 2020

${ }^{4}$ Purwakania Hasan, Psikologi Perkembangan Islam (Jakarta:PT Raja Grafindo Persada,2006), 135
} 
Terjemahnya:

"Allah, dialah yang menciptakan kamu dalam keadaan lemah, kemudian dia menjadikan (kamu) sesudah keadaan lemah itu menjadi kuat, kemudian dia menjadikan (kamu) sesudah kuat itu lemah (kembali) dan berubah. Dia menciptakan apa yang dikehendakinya dan dialah yang maha mengeahui lagi maha kuasa".

Menurut Piaget Perkembangan merupakan suatu proses yang bersifat kumulatif. Artinya, perkembargan terdahulu akan menjadi dasar bagi perkembangan selanjutnya. Dengan demikian, apabila teriadi hambatan pada perkembangan terdahulu maka perkembangan selanjutnya akan memperoleh hambatan. Menurut penulis perkembangan kognitif, yaitu suatu proses perkembangan berfikir anak sesuai dengan bertambahnya usia anak tersebut, dimana proses perkembangan ini dimulai dari sejak lahir sampai dewasa.

Piaget mengemukakan beberapa konsep dan prinsip tentang sifat-sifat perkembangan kognitif anak, diantaranya:

a. Anak adalah belajar yang aktif.

Piaget menyakini bahwa anak tidak hanya mengobservasi dan mengingat apa-apa yang mereka lihat dan dengar secara pasif. Sebaliknya mereka secara natura lmemiliki rasa ingin tahu tentang dunia mereka dan secara aktif berusaha mencari informasi untuk membantu pemahaman dan kesadarannya tentang realitas dunia yang mereka hadapi itu. Dalam memahami dunia mereka secara aktif, anak-anak menggunakan apa yang disebut oleh piaget dengan " schema" (skema), yaitu konsep atau kerangka yang ada dalam pikiran anak yang digunakan untuk mengorganisasikan dan mengimplementasikan informasi.

b. Anak mengorganisasikan apa yang mereka pelajari dari pengalamannya. Anak-anak tidak hanya mengumpulkan apa-apa yang mereka pelajari dari fakta-fakta yang terpisah menjadi satu kesatuan. Sebaliknya anak-anak secara gradual membangun suatu pandangan menyeluruh tentang bagaimana dunia bergerak.

c. Anak menyesuaikan diri dengan lingkungan melalui proses asimilasi dan akomondasi.

Dalam menggunakan dan mengadaptasi skema mereka, ada dua proses yang bertanggung jawab, yaitu assimilation dan accomondation. Asimilasi terjadi ketika seorang anak memasukkan pengetahuan baru kedalam pengetahuan yang sudah ada. Sedanagkan akomondasi terjadi ketika anak menyesuaikan diri pada informasi baru. 
d. Proses ekuilibrasi menunjukkan adanya peningkatan kearah bentukbentuk pemikiranyang lebih kompleks. ${ }^{6}$

Menurut piaget, melalui kedua proses penyesuaian asimilasi dan akomondasi sistem kognisi seseorang berkembang dari satu tahap ke tahap selanjutnya, sehingga kadang-kadang mencapai equilibrium yakni keadaan seimbang antara struktur kognisinya dan pengalamannya dilingkungan. Seseorang akan selalu berupaya agar keadaan seimbang tersebut selalu tercapai dengan menggunakan kedua proses penyesuaian diatas. Namun keadaan seimbang ini tidak dapat bertahan hingga batas waktu yang tidak ditentukan. Sebagai anak yang sedang tumbuh, kadang-kadang mereka berhadapan dengan situasi yang tidak dapat menjelaskan secara memuaskan tentang dunia dalam termologi yang dipahaminya saat ini. Kondisi demikian menimbulkan konflik kognitif atau disequilibrium, yakni semacam ketidaknyamanan mental yang mendorong untuk mencoba membuat pemahaman tentang apa yang mereka saksikan. Dengan melakukan penggantian, mengorganisasi kembali atau mengintegrasikan secara baik sekema-skema mereka (dalam kata-kata lain, melalui akomondasi), anakanak akhirnya mampu memecahkan konflik, mampu memahami kejadiankejadian yang sebelumnya membingungkan, serta kembali mendapatkan keseimbangan pemikiran.

\section{Faktor-faktor Penunjang Perkembangan Kognitif}

Berdasarkan hasil studi Piaget, terdapat lima faktor yang mempengaruhi seseorang pindah tahap perkembangan intelektualnya. Kelima faktor itu adalah: kematangan (maturation), pengalaman fisik (physical experience), pengalaman logika matematika (logico-methematical experience), transmisi sosial (social transmission), dan ekuilibrasi (equilibration). ${ }^{7}$

a. Kematangan yaitu proses perubahan fisiologis dan anatomis, proses pertumbuhan tubuh, sel-sel otak, sistem saraf dan manifestasi lainnya yang mempengaruhi perkembangan kognitif. Kematangan mempunyai peran yang penting dalam perkembangan intelektual. Hal ini ditunjukkan oleh hasil beberapa penelitian yang membuktikan adanya perbedaan rata-rata

\footnotetext{
${ }^{6}$ Ibid.,

${ }^{7}$ http://kustiawati.blogspot.com/2009/04/faktor-faktor-penunjang-perkembangan.html, Diakses 8 Agustus 2020
} 
usia anak pada tahap perkembangan yang sama pada satu masyarakat dengan masyarakat lain yang berbeda.

b. Pengalaman fisik yaitu pengalaman yang melibatkan seseorang untuk berinteraksi dengan lingkungan fisik, memanipulasi obyek-obyek di sekitarnya dan membuat abstraksi dari obyek tersebut. Melalui pengalaman fisik akan terbentuk pengetahuan fisik dalam diri individu, karena pengetahuan fisik merupakan pengetahuan tentang benda-benda yang ada "di luar" dan dapat diamati dalam kenyataan eksternal. Salah satu perkembangan fisik yang mempengaruhi perkembangan kognitif adalah perkembangan otak Otak berkembang paling pesat pada masa bayi. Pada masa kanak-kanak otak tidak bertumbuh dan berkembang sepesat masa bayi. Pada masa awal kanak-kanak, perkembangan otak dan sistem syaraf berkelanjutan. Otak dan kepala bertumbuh lebih pesat daripada bagian tubuh lainnya. Bertambah matangnya otak, dikombinasikan dengan kesempatan untuk mengalami suatu pengalaman melalui rangsangan dari lingkungan menjadi sumbangan terbesar bagi lahirnya kemampuankemampuan kognitif pada anak. Artinya, perkembangan kognitif menjadi optimal jika ada kematangan dalam pertumbuhan otak serta ada rangsangan dari lingkungannya. ${ }^{8}$

c. Pengalaman logika matematika yaitu pengalaman membangun hubunganhubungan atau membuat abstraksi yang didapat dari hasil interaksi terhadap obyek. Dengan pengalaman logika matematika akan terbentuk pengetahuan logika matematika dalam diri individu. Pengetahuan logika matematika merupakan hubungan-hubungan yang diciptakan subyek dan diperlakukan pada obyek-obyek.

d. Transmisi sosial yaitu proses interaksi sosial dalam menyerap unsur-unsur budaya yang berfungsi mengembangkan struktur kognitif. Hal ini dapat terjadi melalui informasi yang datang dari orang tua, guru, teman, media cetak dan media elektronik. Dengan adanya transmisi sosial akan terbentuk pengetahuan sosial dalam diri individu. Pengetahuan sosial merupakan pengetahuan yang didasarkan pada perjanjian sosial, suatu perjanjian atau kebiasaan yang dibuat oleh manusia. Pengetahuan sosial dan pengetahuan fisik merupakan pengetahuan tentang isi yang bersumber dari kenyataan yang ada "di luar", sementara pengetahuan logika matematik mengkonstruksi keadaan nyata tersebut melalui pikiran.

e. Ekuilibrasi yaitu kemampuan untuk mencapai kembali keseimbangan selama periode ketidak seimbangan. Ekuilibrasi merupakan suatu proses untuk mencapai tingkat kognitif yang lebih tinggi melalui asimilasi dan akomodasi. Pada proses ini mengintegrasikan faktor-faktor kematangan, pengalaman fisik, pengalaman logika matematika, dan transmisi sosial. ${ }^{9}$

\footnotetext{
${ }^{8}$ http://asyamforex.blogspot.com/2013/12/makalah-perkembangan-kognitif-peserta.html, Diakses 8 Agustus 2020

${ }^{9}$ Syamsu yusuf, Psikologi Perkembangan Anak Dan Remaja (Bandung:PT Remaja Rosdakarya,2012),6
} 


\section{Tahap perkembangan kognitif}

Piaget juga menyakini bahwa pemikiran seorang anak berkembang melalui serangkaian tahap pemikiran dari masa bayi hingga masa dewasa. Dalam hal ini Piaget membagi perkembangan kognitif ke dalam empat fase, yaitu fase sensorimotor, fase praoperasional, fase operasi konkret, dan fase operasi formal". ${ }^{10}$

a. Fase sensorimotor (usia $0-2$ tahun)

Pada masa dua tahun kehidupannya, anak berinteraksi dengan dunia di sekitarnya, terutama melalui aktivitas sensoris (melihat, meraba, merasa, mencium, dan mendengar) dan persepsinya terhadap gerakan fisik, dan aktivitas yang berkaitan dengan sensoris tersebut. Koordinasi aktivitas ini disebut dengan istilah sensorimotor.

Fase sensorimotor dimulai dengan gerakan-gerakan refleks yang dimiliki anak sejak ia dilahirkan.

1) Periode paling awal tahap sensorimotor adalah periode reflex pada (umur 0-1 bulan) . Ini berkembang sejak bayi lahir sampai sekitar berumur 1 bulan. Pada periode ini, tingkah laku bayi kebanyak bersifat refleks, spontan, tidak disengaja, dan tidak terbedakan. Tindakan seorang bayi didasarkan pada adanya rangsangan dari luar yang ditanggapi secara refleks.

2) Periode 2 yaitu Kebiasaan (umur $1-4$ bulan), Pada periode perkembangan ini, bayi mulai membentuk kebiasan-kebiasaan pertama. Kebiasaan dibuat dengan mencoba-coba dan mengulang-ngulang suatu tindakan. Refleks-refleks yang dibuat diasimilasikan dengan skema yang telah dimiliki dan menjadi semacam kebiasaan, terlebih dari refleks tersebut menghasilkan sesuatu. Pada periode ini, seorang bayi mulai membedakan benda-benda di dekatnya. Ia mulai membedakan diferensiasi akan macam-macam benda yang dipegangnya. Pada periode ini pula, koordinasi tindakan bayi mulai berkembang dengan penggunaan mata dan

\footnotetext{
${ }^{10}$ Ibid.,
} 
telinga. Bayi mulai mengikuti benda yang bergerak dengan matanya. Ia juga mulai menggerakkan kepala kesumber suara yang ia dengar.

3) Periode 3 yaitu Reproduksi kejadian yang menarik (umur $4-8$ bulan), Pada periode ini, seorang bayi mulai menjamah dan memanipulasi objek apapun yang ada di sekitarnya, Tingkah laku bayi semakin berorientasi pada objek dan kejadian di luar tubuhnya sendiri. Ia menunjukkan koordinasi antara penglihatan dan rasa jamah. Pada periode ini, seorang bayi juga menciptakan kembali kejadian-kejadian yang menarik baginya. Ia mencoba menghadirkan dan mengulang kembali peristiwa yang menyenangkan diri (reaksi sirkuler sekunder).

4) Periode 4 yaitu Koordinasi Skemata (umur 8 - 12 bulan), Pada periode ini, seorang bayi mulai membedakan antara sarana dan hasil tindakannya. Ia sudah mulai menggunakan sarana untuk mencapai suatu hasil. Saranasarana yang digunakan untuk mencapai tujuan atau hasil diperoleh dari koordinasi skema-skema yang telah ia ketahui. Bayi mulai mempunyai kemampuan untuk menyatukan tingkah laku yang sebelumnya telah diperoleh untuk mencapai tujuan tertentu. Pada periode ini, seorang bayi mulai membentuk konsep tentang tetapnya (permanensi) suatu benda. Dari kenyataan bahwa dari seorang bayi dapat mencari benda yang tersembunyi, tampak bahwa ini mulai mempunyai konsep tentang ruang.

5) Periode 5 yaitu Eksperimen (umur 12 - 18 bulan), Unsur pokok pada perode ini adalah mulainya anak memperkembangkan cara-cara baru untuk mencapai tujuan dengan cara mencoba-coba (eksperimen) bila dihadapkan pada suatu persoalan yang tidak dipecahkan dengan skema yang ada, anak akan mulai mecoba-coba dengan Trial and Error untuk menemukan cara yang baru guna memecahkan persoalan tersebut atau dengan kata lain ia mencoba mengembangkan skema yang baru. Pada periode ini, anak lebih mengamati benda-benda disekitarnya dan mengamati bagaimana bendabenda di sekitarnya bertingkah laku dalam situasi yang baru. Menurut Piaget, tingkah anak ini menjadi intelegensi sewaktu ia menemukan kemampuan untuk memecahkan persoalan yang baru. Pada periode ini 
pula, konsep anak akan benda mulai maju dan lengkap. Tentang keruangan anak mulai mempertimbangkan organisasi perpindahan benda-benda secara menyeluruh bila benda-benda itu dapat dilihat secara serentak.

6) Periode 6 yaitu Refresentasi (umur 18-24 bulan), Periode ini adalah periode terakhir pada tahap intelegensi sensorimotor. Seorang anak sudah mulai dapat menemukan cara-cara baru yang tidak hanya berdasarkan rabaan fisis dan eksternal, tetapi juga dengan koordinasi internal dalam gambarannya. Pada periode ini, anak berpindah dari periode intelegensi sensori motor ke intelegensi refresentatif. Secara mental, seorang anak mulai dapat menggambarkan suatu benda dan kejadian, dan dapat menyelesaikan suatu persoalan dengan gambaran tersebut. Konsep benda pada tahap ini sudah maju, refresentasi ini membiarkan anak untuk mencari dan menemukan objek-objek yang tersembunyi. Sedangkan konsep keruangan, anak mulai sadar akan gerakan suatu benda sehingga dapat mencarinya secara masuk akal bila benda itu tidak kelihatan lagi.

Karakteristik anak yang berada pada tahap ini adalah sebagai berikut:

a) Berfikir melalui perbuatan (gerak)

b) Perkembangan fisik yang dapat diamati adalah gerak-gerak refleks sampai ia dapat berjalan dan bicara.

c) Belajar mengkoordinasi akal dan geraknya.

d) Cenderung intuitif egosentris, tidak rasional dan tidak logis. ${ }^{11}$

b. Fase Praoperasional (usia 2 - 7 tahun)

Pada fase praoperasional, anak mulai menyadari bahwa pemahamannya tentang benda-benda di sekitarnya tidak hanya dapat dilakukan melalui kegiatan sensorimotor, akan tetapi juga dapat dilakukan melalui kegiatan yang bersifat simbolis. Kegiatan simbolis ini dapat berbentuk melakukan percakapan melalui telepon mainan atau berpura-pura menjadi bapak atau ibu, dan kegiatan simbolis lainnva Fase ini memberikan andil yang besar bagi perkembangan kognitif anak. Pada fase praoperasional, anak tidak berpikir secara operasional yaitu suatu proses berpikir yang dilakukan dengan jalan menginternalisasi suatu aktivitas yang memungkinkan anak mengaitkannya dengan kegiatan yang telah dilakukannya

\footnotetext{
${ }^{11}$ Desmita, Psikologi, 99
} 
sebelumnya. Fase ini merupakan rasa permulaan bagi anak untuk membangun kemampuannya dalam menyusun pikirannya. Oleh sebab itu, cara berpikir anak pada fase ini belum stabil dan tidak terorganisasi secara baik. Fase praoperasional dapat dibagi ke dalam tiga subfase, yaitu subfase fungsi simbolis, subfase berpikir secara egosentris dan subfase berpikir secara intuitif. Subfase fungsi simbolis terjadi pada usia 2 - 4 tahun. Pada masa ini, anak telah memiliki kemampuan untuk menggambarkan suatu objek yang secara fisik tidak hadir. Kemampuan ini membuat anak dapat menggunakan balok-balok kecil untuk membangun rumahrumahan, menyusun puzzle, dan kegiatan lainnya. Pada masa ini, anak sudah dapat menggambar manusia secara sederhana. Subfase berpikir secara egosentris terjadi pada usia 2-4 tahun. Berpikir secara egosentris ditandai oleh ketidakmampuan anak untuk memahami perspektif atau cara berpikir orang lain. Benar atau tidak benar, bagi anak pada fase ini, ditentukan oleh cara pandangnya sendiri yang disebut dengan istilah egosentris. Subfase berpikir secata intuitif terjadi pada usia 4 - 7 tahun. Masa ini disebut subfase berpikir secara intuitif karena pada saat ini anak kelihatannva mengerti dan mengetahui sesuatu, seperti menyusun balok meniadi rumah-rumahan, akan tetapi pada hakikatnya tidak mengetahui alasan-alasan yang menyebabkan balok itu dapat disusun meniadi rumah. Dengan kata lain, anak belum memiliki kemampuan untuk berpikir secara kritis tentang apa yang ada dibalik suatu kejadian.

Karakteristik anak pada tahap ini adalah sebagai berikut:

1) Anak dapat mengaitkan pengalaman yang ada di lingkungan bermainnya dengan pengalaman pribadinya, dan karenanya ia menjadi egois. Anak tidak rela bila barang miliknya dipegang oleh orang lain.

2) Anak belum memiliki kemampuan untuk memecahkan masalah-masalah yang membutuhkan pemikiran "yang dapat dibalik (reversible)." Pikiran mereka masih bersifat irreversible

3) Anak belum mampu melihat dua aspek dari satu objek atau situasi sekaligus, dan belum mampu bernalar (reasoning) secara individu dan deduktif.

4) Anak bernalar secara transduktif (dari khusus ke khusus). Anak juga belum mampu membedakan antara fakta dan fantasi. Kadang-kadang anak seperti berbohong. Ini terjadi karena anak belum mampu memisahkan kejadian sebenarnya dengan imajinasi mereka.

5) Anak belum memiliki konsep kekekalan (kuantitas, materi, luas, berat dan isi). 
6) Menjelang akhir tahap ini, anak mampu memberi alasan mengenai apa yang mereka percayai. Anak dapat mengklasifikasikan objek ke dalam kelompok yang hanya mempunyai satu sifat tertentu dan telah mulai mengerti konsep yang konkrit. ${ }^{12}$

\section{c. Fase Operasi Konkret (usia 7- 11 tahun)}

Pada fase operasi konkret, kemampuan anak untuk berpikir secara logis sudah berkembang, dengan syarat, obyek yang menjadi sumber berpikir logis tersebut hadir secara konkret. Kemampuan berpikir logis ini terwujud dalarn kemampuan mengklasifikasikan obyek sesuai dengan klasifikasinya, mengurutkan benda sesuai dengan urutannya, kemampuan untuk memahami cara pandang orang lain, dan kemampuan berpikir secara deduktif.

\section{d. Fase Operasi Formal (11 tahun sampai usia dewasa)}

Fase operasi formal ditandai oleh perpindahan dari cara berpikir konkret ke cara berpikir abstrak. Kemampuan berpikir abstrak dapat dilihat dari kemampuan mengemukakan ide-ide, memprediksi kejadian yang akan terjadi, dan melakukan proses berpikir ilmiah, yaitu mengemukakan hipotesis dan menentukan cara untuk membuktikan kebenaran hipotesis.

Menurut piaget, perkembangan dari masing-masing tahap tersebut merupakan hasil perbaikan dari perkembangan tahap sebelumnya. ${ }^{13} \mathrm{Hal}$ ini menurut tahapan piaget, setiap individu akan melewati serangkaian perubahan kualitatif yang bersifat invariant, selalu tetap, tidak melompat atau mundur. Perubahan-perubahan dalam kualitatif ini terjadi karena tekanan biologis untuk menyesuaikan diri dengan lingkungan serta adanya pengorganisasian struktur berfikir. Dari sudut biologis, piaget melihat adanya sistem yang mengatur dari dalam sehingga organisme mempunyai sistem pencernaan, peredaran darah, sistem pernafasan dan lain-lain. Hal yang sama juga terjadi pada sistem kognisi, di mana adanya sistem yang mengatur dari dalam yang kemudian dipengaruhi oleh faktor-faktor lingkungan.

Untuk menunjukkan struktur kognitif yang mendasari pola-pola tingkah laku yang terorganisasi, piaget menggunakan istilah skemadan adaptasi.

\footnotetext{
${ }^{12}$ yusuf, Psikologi, 8

${ }^{13}$ Desmita, Psikologi Perkembangan (Bandung:PT Remaja Rosdakarya,2009), 47
} 
Skema (struktur kognitif) adalah proses atau cara mengorganisasi dan merespon berbagai pengalaman. Dengan kata lain, skema adalah suatu pola sistematis dari tindakan, perilaku, pikiran, dan strategi pemecahan masalah yang memberikan suatu kerangka pemikiran dalam menghadapi berbagai tantangan dan jenis situasi.

Adaptasi (struktur fungsional) adalah sebuah istilah yang digunakan piaget untuk menunjukkan pentingnya pola hubungan individu dengan lingkungan dalam proses perkembangan kognitif. Adaptasi ini muncul dengan sendirinya ketika bayi tersebut mengadakan interaksi dengan dunia disekitarnya. Mereka akan belajar menyesuaikan diri dan mengatasinya sehingga kemampuan mentalnya akan berkembang dengan sendirinya. Menurut piaget adaptasi ini terdiri dari dua proses yang saling melengkapi yaitu asimilasi dan akomondasi.

Asimilasi, dari sudut biologis asimilasi adalah integrasi antara elemenelemen eksternal (dari luar) terhadap struktur yang sudah lengkap pada organsme. Asimilasi kognitif mencangkup perubahan objek eksternal menjadi stuktur pengetahuan internal. Proses asimilasi ini didasarkan atas kenyataan bahwa setiap saat manusia selalu mengasimilasikan informasi-informasi yang sampai kepadanya, dimana kemudian informasi-informasi tersebut dikelompokkan kedalam istilah-istilah yang sebelumnya sudah mereka ketahui.

Akomondasi, adalah menciptakan langkah baru atau memperbarui, atau menggabung-gabungkan istilah lama untuk menghadapi tantangan baru. Akomondasi kognitif berarti mengubah struktur kognitif yang telah dimiliki sebelumnya untuk disesuaikan denagan objek stimulus eksternal. Jadi kalau pada asimilasi terjadi perubahan pada objeknya, maka pada akomondasi perubahan terjadi pada subjeknya, sehingga ia dapat menyesuaikan diri dengan objek yang ada di luar dirinya. Sturtur kognitif yang sudah ada dalam diri seseorang mengalami perubahan supaya sesuai dengan rangsangan-rangsangan dari objeknya.

Piaget mengemukakan bahwa setiap organisme yang ingin mengadakan penyesuaian (adaptasi) dengan lingkungannya harus mencapai keseimbangan (ekuilibrium), yaitu antara aktivitas individu terhadap lingkungan (asimilasi) dan 
aktivitas lingkungan terhadap individu (akomondasi). Hal ini berarti, ketika individu bereaksi terhadap lingkungan, dia menggabungkan stimulus dunia luar dengan struktur yang sudah ada, dan inilah asimilasi. Pada saat yang sama, ketika lingkungan bereaksi terhadap individu, dan individu mengubah supaya sesuai dengan stimulus dunia luar, maka inilah yang disebut akomondasi.

\section{Stimulasi Dan Optimalisasi Kognitif}

\section{a. Stimulasi}

Stimulasi adalah kegiatan merangsang kemampuan dasar anak yang datangnya di luar individu anak agar anak tumbuh dan berkembang secara optimal. ${ }^{14}$ Setiap anak perlu mendapat stimulasi rutin sedini mungkin dan terusmenerus pada setiap kesempatan. Anak yang mendapatkan stimulasi lebih cepat berkembang dibandingkan dengan yang kurang atau tidak mendapat stimulasi. Kurangnya stimulasi dapat menyebabkan penyimpangan tumbuh kembang anak bahkan bisa menyebabkan gangguan yang menetap.

Stimulasi juga merupakan penguat hubungan antara orang tua dengan anaknya. Misalnya seorang ibu yang memberikan stimulasi/permainan kepada anaknya, menyebabkan anak tersebut menjadi senang dan berinisiatif untuk melakukan permainan dengan ibunya sehingga menciptakan suasana kasih sayang. Dalam melakukan stimulasi ada prinsip dasar yang perlu diperhatikan yaitu :

1) Stimulasi dilakukan dengan dilandasi rasa cinta dan kasih sayang.

2) Selalu tunjukkan sikap dan perilaku yang baik karena anak akan meniru tingkah laku orang-orang yang terdekat dengannya.

3) Berikan stimulasi sesuai dengan kelompok umur

4) Lakukan stimulasi dengan mengajak anak bermain, bernyanyi, menyenangkan, tanpa paksaan, tanpa hukuman dan bervariasi.

5) Lakukan stimulasi secara bertahap dan berkelanjutan sesuai umur anak.

6) Gunakan alat bantu atau permainan yang sederhana, aman dan ada di sekitar anak.

7) Berikan kesempatan yang sama pada anak laki-laki dan perempuan.

8) Anak selalu diberi pujian, bila perlu diberi hadiah atas keberhasilannya. ${ }^{15}$

\footnotetext{
${ }^{14}$ Dian, blogspot.com.2012/05/karya-tulis-ilimiah-stimulasi-anak-usia.html, Diakses 8 Agustus 2020

${ }^{15}$ Muslam, Pengembangan Kurikulum PAI (Semarang: PKPI2, 2008), 7
} 
b. optimalisasi

Optimalisasi berasal dari kata optimal artinya terbaik atau tertinggi. Mengoptimalkan berarti menjadi paling baik atau paling tinggi sedangkan optimalisasi adalah proses mengoptimalkan sesuatu dengan kata lain proses menjadikan sesuatu menjadi paling baik atau paling tinggi.

Cara Optimalkan Pertumbuhan Otak yaitu Kasih sayang dan stimulasi dini adalah bekal pembentukan otak anak yang cerdas. Lengkapi dengan pola tidur berkualitas sejak bayi supaya otak buah hati tumbuh optimal. Bayi baru lahir, dengan segala keterbatasannya hanya mampu mengomunikasikan apa yang diinginkan dan rasakan melalui tangisan. Untuk mampu mengerti arti tangisan si kecil, seorang ibu haruslah "dekat" dengan bayinya. Kedekatan ini tak sebatas kontak fisik, tetapi juga kasih sayang sejati yang mengikat ibu-bayi dalam ikatan emosional yang kuat.

Perkembangan kognitif adalah tahap-tahap perkembangan kognitif manusia mulai dari usia anak-anak sampai dewasa, mulai dari proses-proses berpikir secara konkret sampai dengan yang lebih tinggi yaitu konsep-konsep anstrak dan logis. Jean Piaget seorang pakar yang banyak melakukan penelitian tentang perkembangan kemampuan kognitif manusia, mengemukakan dalam teorinya bahwa kemampuan kognitif manusia terdiri atas 4 tahap dari lahir hingga dewasa. Tahap dan urutan berlaku untuk semua usia tetapi usia pada saat seseorang mulai memasuki tahap tertentu tidak sama untuk setiap orang.

Keempat tahap perkembangan itu digambarkan dalam teori Piaget sebagai berikut :

1). Tahap sensorimotor: umur $0-2$ tahun (anak mengalami dunianya melalui gerak dan inderanya serta mempelajari permanensi obyek).

2). Tahap pra-operasional: umur $2-7$ tahun (Ciri pokok perkembangannya adalah penggunaan symbol/bahasa tanda dan konsep intuitif).

3). Tahap operasional konkret: umur 7 - 11 tahun (anak mulai berpikir secara logis tentang kejadian-kejadian konkret)

4). Tahap operasional formal: umur 11 ke atas. (Ciri pokok perkembangannya adalah hipotesis, abstrak, deduktif dan induktif serta logis dan probabilitas ). 
Stimulasi adalah kegiatan merangsang kemampuan dasar anak yang datangnya di luar individu anak agar anak tumbuh dan berkembang secara optimal. optimalisasi adalah proses mengoptimalkan sesuatu dengan kata lain proses menjadikan sesuatu menjadi paling baik atau paling tinggi.

\section{B. Peserta didik Sebagai Subjek Belajar}

Peserta didik adalah salah satu komponen manusiawi yang menempati posisi sentral dalam proses pembelajaran. Didalam proses belajar-mengajar, peserta didiksebagai pihak yang ingin meraih cita-cita dan memiliki tujuan dan kemudia ingin mencapainya secara optimal. Jadi dalam proses pembelajaran yang perlu diperhatikan pertama kali adalah peserta didik, bagaimana keadaan dan kemampuannya, baru setelah itu menentukan komponen-komponen yang lain. Apa bahan yang diperlukan, bagaimana cara yang tepat untuk bertindak, alat dan fasilitas apa yang cocok dan mendukung, semua itu harus disesuaikan dengan keadaan atau karakteristik peserta didik. Itulah sebabnya peserta didik merupakan subjek belajar. Ada beberapa hal yang harus dipenuhi oleh peserta didik sebagai subjek belajar yaitu:

1. Mememahami dan menerima keadaan jasmani

Sesuai dengan teori kebutuhan menurut Maslow, kebutuhan jasmaniah merupakan kebutuhan dasar setiap manusia yang bersifat instinktif dan tidak dipengaruhi oleh lingkungan dan pendidikan. Kebutuhan-kebutuhan jasmaniah peserta didik yang perlu mendapat perhatian dari guru di sekolah antara lain: makan, minum, pakaian, oksigen, istirahat, kesehatan jasmani, gerak-gerak jasmani, serta terhindar dari berbagai ancaman. Apabila kebutuhan jasmaniah ini tidak terpenuhi, di samping mempengaruhi pembentukan pribadi dan perkembangn psikososial peserta didik, juga akan sangat berpengaruh terhadap proses belajar mengajar di sekolah

2. Memperoleh hubungan yang memuaskan dengan teman-teman sebayanya.

Hubungan dengan teman sebaya tampak mempunyai berbagai macam fungsi, yang banyak di antaranya dapat memfasilitasi proses belajar dan perkembangan peserta didik. Melalui hubungan teman sebaya, peserta didik memperoleh kesempatan untuk belajar keterampilan sosial yang penting untuk 
kehidupannya, terutama keterampilan yang dibutuhkan untuk memulai dan memelihara hubungan sosial dan untuk memecahkan konflik sosial, yang mencakup keterampilan berkomunikasi, berkompromi, dan berdiplomasi. Di samping mengajari peserta didik cara bertahan hidup di kalangan sesamanya, hubungan teman sebaya memberikan kepadap peserta didik konteks untuk dapat membandingkan dirinya dengan orang lain serta memberi kesempatan untuk belajar berkelompok

3. Mencapai hubungan yang lebih "matang" dengan orang dewasa

Akibat adanya kematangan organ reproduksi memang diharapkan peserta didik dapat mencari dapat memperoleh teman baru dan menjadi matang berhubungan dengan teman sebaya lawan jenis dalam kelompok mereka.buruknya dari pergaulan tersebut mereka yang tidak diterima oleh kelompok lain membuat kelompok sendiri yang dikenal sebagai "gang."

4. Mencapai kematangan emosional

Tindakan masa kecil diharapkan dihilangkan sebab pentingnya kebebasan emosi ini dapat memupuk mentalitas dalam menyelesaikan setiap masalah dan dapat bertanggung jawab sendiri terhadap setiap langkah pilihannya yang ditempuh.

5. Mencapai kematangan intelektual

Kemampuan untuk meletakkan hubungan dari proses berpikir. dapat menyelesaikan persoalan dalam waktu yang singkat, memahami masalahnya lebih cepat dan cermat, serta mampu bertindak cepat

6. Membentuk pandangan hidup

Peserta didik sangat tertarik pada persoalan yang menyangkut kehidupan dan falsafah hidup, serta soal kaegamaan. Mereka tertarik pada tujuan hidup, memusatkan perhatian pada standar perilaku pada diri, keluarga dan orang lain. Sehingga dapat menuntun dan mewarnai berbagai aspek kehidupannya dalam masa dewasa dan selanjutnya(berguna sebagai kendali atau kemudi dalam kehidupan). ${ }^{16}$

\footnotetext{
${ }^{16}$ Darnis Arief dan Khairanis, Perkembangan dan Belajar Peserta Didik (Padang: DIP Universitas Negeri Padang, 2000), 14
} 
Belajar mempunyai peranan yang penting dalam kehidupan. Dengan belajar orang jadi pandai, ia akan mengetahui terhadap segala sesuatu yang dipelajarinya. Tanpa belajar, orang tidak akan mengetahui sesuatu pun, disamping belajar dapat untuk menambah ilmu pengetahuan baik teori maupun praktek, belajar juga dinilai sebagai ibadah kepada Allah Swt. Orang yang belajar sungguh-sungguh disertai niat ikhlas ia akan memperoleh pahala yang banyak. Belajar juga dinilai sebagai suatu perbuatn yang dapat mendatangkan ampunan dari Allah Swt orang yang belajar dengan niat ikhlas kepada Allah Swt diampuni dosanya. ${ }^{17}$

\section{Karakteristik Peserta didik}

Karakteristik peserta didik adalah keseluruhan kelakuan dan kemampuan yang ada pada peserta didiksebagai hasil dari pembawaan dan lingkungan sosialnya sehingga menentukan pola aktivitas dalam meraih cita-cintanya. Dengan demikian, penentuan tujuan belajar itu sebenarnya harus dikaitkan atau disesuaikan dengan keadaan atau karakteristik peserta didik itu sendiri.

Ada tiga hal hal yang perlu diperhatikan dalam karakteristik peserta didik yaitu:

1. Karakteristik atau keadaan yang berkenaan dengan kemampuan awal seperti misalnya kemampuan intelektual, kemampuan berfikir, mengucapkan hal-hal yang berkaitan dengan aspek psikomotor dan lainnya.

2. Karakteristik yang berhungan dengan latar belakang dan status sosial (socioculture)

3. Karakteristik yang berkenaan dengan perbedaan-perbedaan kepribadian seperti sikap, perasaan, minat dan lain-lain. ${ }^{18}$

Pengetahuan mengenai karakteristik peserta didik ini memiliki arti yang cukup penting dalam interaksi pembelajaran. Terutama bagi guru, informasi mengenai karakteristik peserta didiksenantiasa akan sangat berguna dalam memilih dan menentukan pola-pola pengajaranyang lebih baik, yang dapat menjamin kemudahan belajarbagi setiap peserta didik. Pakar pembelajaran sependapat, bahwa:

\footnotetext{
${ }^{17}$ Moh. Roqib, Ilmu pendidikan Islam (Yogyakarta: LkiS Yogyakarta, 2009), 23

${ }^{18} \mathrm{http}: / /$ alenmarlissmpnl gresik.wordpress.com/2009/12/29/hak-dan-kewajiban-pesertadidik-berdasarkan-uu-no-20-th-2003/, Diakses 8 Agustus 2020
} 
Karakteristik peserta didik adalah satu variabel yang paling berpengaruh dalam pembelajaran. Model pembelajaran apapun yang dikembangkan dan/atau strategi apapun yang dipilih untuk keperluan pembelajaran haruslah berpijak pada karakteristik perseorangan dan/atau kelompok dari siapa yang belajar", 19

Pendapat dari pakar lain juga mengatakan bahwa:

Karakteristik peserta didik didefinisikan sebagai aspek atau kualitas perseorangan peserta didikseperti bakat, motivasi belajar, dan kemampuan awal yang telah dipelajari dan dimilikinya dan berguna sebagai pijakan dalam pemilihan strategi pembelajaran yang optimal. Hal ini sangatlah penting dalam meningkatkan kebermaknaan pembelajaran yang selanjutnya membawa dampak dalam memudahkan proses internal yang berlangsung ketika peserta didikmengkonstruksi informasi yang disampaikan kepadanya. $^{20}$

Karakteristik peserta didik juga di gambarkan dalam surat Al-Kahfi ayat 60 yang berbunyi :

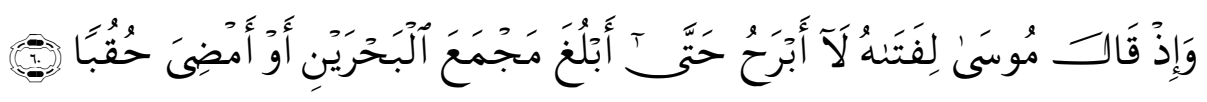

Terjemahnya:

"Dan (ingatlah) ketika musa berkata kepada muridnya : "aku tidak akan berjalan (berhenti) sebelum sampai ke pertemuan dua buah lautan, atau aku akan berjalan sampai bertahun-tahun". ${ }^{21}$

Nabi Musa A.S pada ayat di atas nampak memiliki semangat yang tinggi untuk terus menerus belajar walaupun dia telah menjadi seorang guru. Ini menunjukan bahwa salah satu karakteristik yang harus dimiliki peserta didik adalah semangat untuk belajar. Al-qur'an memberikan gambaran dengan beberapa kisahnya tentang perilaku yang membedakan seseorang dengan yang lain, seorang murid yang ideal hendaknya memiliki sikap sebagai berikut :

19 Nur Uhbiyati, Ilmu Pendidikan Islam (IPI) Untuk IAIN, STAIN, PTAIS (Bandung: Pustaka Setia, 1998), 13

${ }^{20}$ Abd. Mujid dalam Ramayulis, Psikologi Agama (Jakarta: Kalam Mulia, 2004), 9

${ }^{21}$ Departemen Agama RI, Alqur'an, 301 
1. peserta didik hendaknya mempunyai niat yang suci dalam hatinya sehingga mudah mencerna dan memahami pelajaran.

2. Seorang peserta didikharuslah memiliki motivasi yang tinggi untuk menggali dan memahami suatu ilmu.

3. Peserta didik harus tekun, dengan memperhatikan pelajaran secara serius.

4. Patuh dan hormat terhadap guru

5. Hendaklah bermusyawarah dalam menghadapi permasalahan yang sulit ketika menuntut ilmu. ${ }^{22}$

Karakteristik (karakteristik, ciri, tabiat; sifat-sifat kejiwaan, akhlak atau budi pekerti) Peserta didik yang mempengaruhi kegiatan belajar peserta didik antara lain:

1. Anak merasa kesepian dan menderita. Dia menganggap tak ada orang yang mau mengerti, memahami, dirinya, dan menjelaskan hal-hal yang dirasakan-nya.

2. Reaksi pertama anak ialah protes terhadap sekitarnya, yang dirasakan tibatiba memusuhi, menerlantarkan, dan tidak mau mengerti.

3. Memerlukan teman yang dapat memahami, menolong, dan turut merasakan suka-duka yang dialaminya.

4. Mulai tumbuh dorongan untuk mencari pedoman hidup, mencari sesuatu yang dipandang bernilai, pantas dijunjung tinggi dan dipuja.

5. Anak mengalami goncangan batin. Dia tidak mau memakai lagi pedoman hidup masa kanak-kanaknya, tetapi ia juga belum mempunyai pedoman hidup yang baru.

6. Merasa tidak tenang, banyak kontradiksi dalam dirinya. Dia merasa mampu, tetapi tidak tahu bagaimana mewujudkannya.

7. Anak mulai mencari dan membangun pendirian atau pandangan hidupnya. $^{23}$

\section{Perkembangan Peserta didik}

1. Perkembangan Fisik Peserta didik

Di dalam Kurikulum 2013 pola pembelajaran berpusat pada peserta didik. Peserta didik memiliki pilihan-pilihan terhadap materi yang akan dipelajari dan gaya belajarnya (learning style) untuk memiliki kompetensi yang diharapkan oleh Kurikulum 2013. Karakteristik setiap peserta didik di dalam proses pembelajaran, agar tujuan pembelajaran dapat tercapai. Hal pertama yang harus Anda ketahui adalah mengenal karakter peserta didik yang berkaitan dengan aspek perkembangan fisik peserta didik. Seperti kita ketahui fisik peserta didik

\footnotetext{
${ }^{22}$ Ramayulis, Ilmu Pendidikan Islam (Jakarta: Kalam Mulia, 2008), 12

${ }^{23}$ Ibid, 28
} 
mengalami perkembangan yang signifikan pada saat mereka menginjak remaja atau pada saat mereka di sekolah menengah. Pada dasarnya perkembangan merujuk kepada perubahan sistematis tentang fungsi-fungsi fisik dan psikis. Perubahan fisik meliputi perkembangan biologis dasar sebagai hasil dari konsepsi, dan hasil dari interaksi proses biologis dan genetika dengan lingkungan. Sementara perubahan psikis menyangkut keseluruhan karakteristik psikologis individu, seperti perkembangan kognitif, emosi, sosial, dan moral.

Perkembangan fisik atau pertumbuhan biologis (biological growth) merupakan salah satu aspek penting dari perkembangan individu. Pertumbuhan fisik adalah perubahan-perubahan fisik yang terjadi dan merupakan gejala primer dalam pertumbuhan remaja. Fisik atau tubuh manusia merupakan sistem organ yang kompleks dan sangat mengagumkan. Semua organ ini terbentuk pada periode pranatal (dalam kandungan). ${ }^{24}$

Berkaitan dengan perkembangan fisik ini Kuhlen dan Thompson dalam Hasan mengemukakan bahwa perkembangan fisik individu meliputi empat aspek, yaitu: Sistem syaraf, yang sangat mempengaruhi perkembangan kecerdasan dan emosi, (a) Otot-otot, yang mempengaruhi perkembangan kekuatan dan kemampuan motorik, (b) Sistem syaraf yang sangat memengaruhi perkembangan kecerdasan dan emosi, (c) Kelenjar Endokrin, yang menyebabkan munculnya pola-pola tingkah laku baru, seperti pada usia remaja berkembang perasaan senang untuk aktif dalam suatu kegiatan, yang sebagian anggotanya terdiri atas lawan jenis, (d) Struktur fisik/tubuh, yang meliputi tinggi, berat, dan proporsi. $^{25}$

Seifert dan Hoffnung dalam Gunarsa, berpendapat perkembangan fisik meliputi perubahan-perubahan dalam tubuh (seperti: pertumbuhan otak, sistem saraf, organ-organ indrawi, pertambahan tinggi dan berat, hormon, dan lain-lain), dan perubahan-perubahan dalam cara individu dalam menggunakan tubuhnya (seperti perkembangan keterampilan motorik dan perkembangan seksual), serta

\footnotetext{
${ }^{24}$ Chalidjah Hasan, Dimendi-Dimensi Pendidikan (Surabaya : Al-Ikhlas, 2013), 84

${ }^{25}$ Ibid.,
} 
perubahan dalam kemampuan fisik (seperti penurunan fungsi jantung, penglihatan, dan sebagainya). ${ }^{26}$

Berdasarkan pendapat di atas, jelaslah bahwa perkembangan fisik setiap peserta didikdipengaruhi oleh berbagai faktor seperti telah dijelaskan di atas. Oleh sebab itu Anda sebagai pendidik harus mengenali karakteristik perkembangan peserta didikdari segi fisik, agar Anda bisa lebih memahami situasi pembelajaran di dalam kelas dan apabila ada situasi yang tidak Anda harapkan suatu saat terjadi, maka Anda akan lebih memahami situasi tersebut. Kalau Anda bisa memahami kejadian tersebut, maka Anda pun diharapkan akan bisa mencari solusinya dan kalau situasi sudah dapat dikuasai maka proses pembelajaran diharapkan akan lebih lancar dan tujuan akan tercapai.

\section{Perkembangan Kognitif Peserta didik}

Proses pembelajaran setiap peserta didik berlangsung baik di sekolah maupun dalam lingkungan keluarga. Sehingga kemampuan kognitif sangat diperlukan peserta didikdalam proses pembelajaran tersebut. Perkembangan kognitif merupakan salah satu aspek yang sangat penting dalam perkembangan peserta didik. Kita ketahui bahwa peserta didik merupakan objek yang berkaitan langsung dengan proses pembelajaran, sehingga perkembangan kognitif sangat menentukan keberhasilan peserta didikdalam belajar. Kognitif atau pemikiran adalah istilah yang digunakan oleh ahli psikologi untuk menjelaskan semua aktivitas mental yang berhubungan dengan persepsi, pikiran, ingatan dan Pengolahan informasi yang memungkinkan seseorang memperoleh pengetahuan, memecahkan masalah, dan merencanakan masa depan, atau semua proses psikologis yang berkaitan bagaimana individu mempelajari, memperhatikan, mengamati, membayangkan, memperkirakan, menilai dan memikirkan lingkungannya. ${ }^{27}$

Perkembangan kognitif pada peserta didik merupakan suatu pembahasan yang cukup penting bagi guru maupun orang tua. Perkembangan kognitif pada anak merupakan kemampuan anak untuk berpikir lebih kompleks serta

${ }^{26}$ Singgih D. Gunarsa, Psikologi Untuk Keluarga (Jakarta: BPK. Gunung Mulia, 1979), 132.

$$
{ }^{27} \text { Ibid., }
$$


kemampuan melakukan penalaran dan pemecahan masalah yang termasuk dalam proses psikologis yang berkaitan dengan bagaimana individu mempelajari dan memikirkan lingkungannya. Karakteristik perkembangan kognitif peserta didikjuga harus dapat dipahami semua pihak. Dengan pemahaman pada karakteristik perkembangan peserta didik, guru dan orang tua dapat mengetahui sebatas apa perkembangan yang dimiliki peserta didiknya sesuai dengan usia mereka masing-masing, sehingga guru dan orang tua dapat menerapkan ilmu yang sesuai dengan kemampuan kognitif masing-masing anak didik. ${ }^{28}$

Tidak kalah penting, guru juga harus mengetahui tentang faktor-faktor yang mempengaruhi peserta didik. Yang sangat sentral dalam faktor-faktor yang mempengaruhi perkembangan kognitif adalah gaya pengasuhan dan lingkungan. Biasanya gaya pengasuhan lebih diterapkan pada peserta didik. Pada pengasuhan ini merupakan cikal-bakal perkembangan kognitif tersebut, karena ketika anak diasuh secara tidak sesuai dengan semestinya, ini akan berakibat pada perkembangan kognitif peserta didik, bahkan pada perkembangan mental anak tersebut. Lingkungan pun sangat berpengaruh pada perkembangan kognitif, semakin buruk lingkungan maupun pergaulan seseorang maka kemungkinan pengaruh lingkungan pada perkembangan kognitif peserta didik semakin besar.

Dari uraian di atas jelaslah bahwa perkembangan kognitif peserta didik sangat berpengaruh terhadap proses pembelajaran dan hasil yang dicapai.

3. Perkembangan Sosial-emosional peserta didik

Selain perkembangan karakteristik fisik dan kognitif peserta didik, yang tidak kalah penting adalah perkembangan sosial-emosional peserta didik. Sosioemosional berasal dari kata sosial dan emosi. Perkembangan sosial adalah pencapaian kematangan dalam hubungan atau interaksi sosial. Dapat juga diartikan sebagai proses belajar untuk menyesuaikan diri dengan norma-norma kelompok, tradisi dan moral agama. Sedangkan emosi merupakan faktor dominan yang mempengaruhi tingkah laku individu, dalam hal ini termasuk pula perilaku belajar. Emosi dibedakan menjadi dua, yakni emosi positif dan emosi negatif.

${ }^{28}$ Syaiful Bahri Djamarah, Guru dan Anak Didik dalam Interaksi Edukatif, (Jakarta: Rineka Cipta, 2000), 40 
Emosi positif seperti perasaan senang, bergairah, bersemangat, atau rasa ingin tahu yang tinggi akan mempengaruhi individu untuk mengonsentrasikan dirinya terhadap aktivitas belajar.

Emosi negatif sperti perasaan tidak senang, kecewa, tidak bergairah, individu tidak dapat memusatkan perhatiannya untuk belajar, sehingga kemungkinan besar dia akan mengalami kegagalan dalam belajarnya. Selain itu, dari segi etimologi, emosi berasal dari akar kata bahasa Latin 'movere' yang berarti 'menggerakkan, bergerak'. Kemudian ditambah dengan awalan 'e-' untuk memberi arti 'bergerak menjauh'. Makna ini menyiratkan kesan bahwa kecenderungan bertindak merupakan hal mutlak dalam emosi. ${ }^{29}$

Perkembangan sosio-emosional peserta didik termasuk suatu pembahasan yang sangat penting karena dengan mengetahui perkembangan sosio-emosional peserta didik, para pendidik dapat mengambil tindakan pada permasalahan peserta didik dengan berbagai karakteristik dan sifat yang berbeda-beda. Sosio-emosional adalah perubahan yang terjadi pada diri setiap individu dalam warna afektif yang menyertai setiap keadaan atau perilaku individu. Dalam pembahasan sosioemosional ini lebih ditekankan dalam sosio-emosional pada remaja. Pada masa remaja, tingkat karakteristik emosional akan menjadi drastis tingkat kecepatannya. Gejala-gejala emosional para remaja seperti perasaan sayang, cinta dan benci, harapan-harapan dan putus asa, perlu dicermati dan dipahami dengan baik. Sebagai pendidik. kita harus mengetahui setiap aspek yang berhubungan dengan perubahan tingkah laku dalam perkembangan remaja, serta memahami aspek atau gejala tersebut sehingga kita bisa melakukan komunikasi yang baik dengan remaja. Perkembangan emosi remaja merupakan suatu titik yang mengarah pada proses dalam mencapai kedewasaan. Meskipun sikap kanak-kanak akan sulit dilepaskan pada diri remaja karena pengaruh didikan orang tua.

Faktor yang sangat memengaruhi perkembangan peserta didik pada usia remaja yaitu didikan orang tua, lingkungan sekitar tempat tinggal dan perlakuan guru di sekolah. Pengaruh sosio-emosional yang baik pada remaja terhadap diri sendiri yaitu untuk mengendalikan diri, memutuskan segala sesuatu dengan baik,

\footnotetext{
${ }^{29}$ Mustaqim, Psikologi Pendidikan (Yogyakarta: Pustaka Pelajar, 2001), 94
} 
serta bisa lebih matang merencanakan segala hal yang akan diputuskannya, sedangkan terhadap orang lain, yaitu mampu menjalin kerjasama yang baik, saling menghargai dan mampu memposisikan diri di lingkungan dengan baik.

Agar seorang peserta didik dapat memiliki kecerdasan emosi dengan baik haruslah dibentuk sejak usia dini, karena pada saat itu sangat menentukan pertumbuhan dan perkembangan manusia selanjutnya. Sebab pada usia ini dasardasar kepribadian anak telah terbentuk. Jelaslah sudah betapa pentingnya seorang pendidik memahami perkembangan sosio-emosional peserta didik, agar dalam proses pembelajaran perkembangan sosio-emosional peserta didik yang berbedabeda dapat diatasi dengan baik.

\section{Perkembangan Moral dan Spritual peserta didik}

Perkembangan moral dan spiritual peserta didik adalah dua hal yang tidak dapat dipisahkan dari kehidupan kita semua. Demikian pula dalam proses pendidikan peserta didikbaik itu di sekolah maupun di rumah. Teori Kohlberg telah menekankan bahwa perkembangan moral didasarkan terutama pada penalaran moral dan berkembang secara bertahap yaitu: Penalaran prakovensional, konvensional, dan pascakonvensional. ${ }^{30}$

\section{a. Tingkat Satu: Penalaran Prakonvesional}

Penalaran prakonvensional adalah tingkat yang paling rendah dalam teori perkembangan moral Kohlberg. Pada tingkat ini, anak tidak memperlihatkan internalisasi nilai-nilai moral, penalaran moral dikendalikan oleh imbalan (hadiah) dan hukuman ekternal.

\section{b. Tingkat Dua: Penalaran Konvensional}

Penalaran konvensional adalah tingkat kedua atau tingkat menengah dari teori perkembangan moral Kohlberg. Internalisasi individu pada tahap ini adalah menengah. Seorang mentaati standar-standar (internal) tertentu, tetapi mereka tidak mentaati standar-standar (internal) orang lain, seperti orangtua atau masyarakat.

\footnotetext{
${ }^{30}$ Muhabbin Syah, Psikologi Pendidikan (Bandung: Remaja Rosda Karya, 1995), 225
} 
c. Tahap Tiga: Penalaran Pascakonvensional

Penalaran pascakonvensional adalah tingkat tertinggi dari teori perkembangan moral Kohlberg. Pada tingkat ini, moralitas benar-benar diinternalisasikan dan tidak didasarkan pada standar-standar orang lain. Seorang mengenal tindakan moral alternatif, menjajaki pilihan-pilihan, dan kemudian memutuskan berdasarkan suatu kode moral pribadi. Spiritual berasal dari bahasa latin "spiritus" yang berarti nafas atau udara, spirit memberikan hidup, menjiwai seseorang. Spiritual meliputi komunikasi dengan Tuhan dan upaya seseorang untuk bersatu dengan Tuhan, spiritualitas didefinisikan sebagai suatu kepercayaan akan adanya suatu kekuatan atau suatu yang lebih agung dari diri sendiri.

Karakteristik spiritual yang utama meliputi perasaan dari keseluruhan dan keselarasan dalam diri seorang, dengan orang lain, dan dengan Tuhan atau kekuatan tertinggi sebagai satu penetapan. Orang-orang, menurut tingkat perkembangan mereka, pengalaman, memperhitungkan keamanan individu, tandatanda kekuatan, dan perasaan dari harapan. Hal itu tidak berarti bahwa individu adalah puas secara total dengan hidup atau jawaban yang mereka miliki. Seperti setiap hidup individu berkembang secara normal, timbul situasi yang menyebabkan kecemasan, tidak berdaya, atau kepusingan. Karakteristik kebutuhan spiritual meliputi:

1) Kepercayaan

2) Pemaafan

3) Cinta dan hubungan

4) Keyakinan, kreativitas dan harapan

5) Maksud dan tujuan serta anugrah dan harapan. ${ }^{31}$

Karakteristik dari kebutuhan spiritual ini menjadi dasar dalam menentukan karakteristik dari perubahan fungsi spiritual yang akan mengarahkan individu dalam berperilaku, baik itu kearah perilaku yang adaptif maupun perilaku yang maladaptif.

\footnotetext{
${ }^{31}$ Suparno dan A. Suhaenah, Membangun Kompetensi Belajar (Jakarta: Direktorat Jendral Pendidikan Tinggi, 2001), 19
} 


\section{KESIMPULAN}

Perkembangan kognitif pada peserta didik merupakan suatu pembahasan yang cukup penting bagi guru maupun orang tua. Perkembangan kognitif pada anak merupakan kemampuan anak untuk berpikir lebih kompleks serta kemampuan melakukan penalaran dan pemecahan masalah yang termasuk dalam proses psikologis yang berkaitan dengan bagaimana individu mempelajari dan memikirkan lingkungannya. Karakteristik perkembangan kognitif peserta didikjuga harus dapat dipahami semua pihak. Dengan pemahaman pada karakteristik perkembangan peserta didik, guru dan orang tua dapat mengetahui sebatas apa perkembangan yang dimiliki peserta didiknya sesuai dengan usia mereka masing-masing, sehingga guru dan orang tua dapat menerapkan ilmu yang sesuai dengan kemampuan kognitif masing-masing anak didik.

Tidak kalah penting, guru juga harus mengetahui tentang faktor-faktor yang mempengaruhi peserta didik. Yang sangat sentral dalam faktor-faktor yang mempengaruhi perkembangan kognitif adalah gaya pengasuhan dan lingkungan. Biasanya gaya pengasuhan lebih diterapkan pada peserta didik. Pada pengasuhan ini merupakan cikal-bakal perkembangan kognitif tersebut, karena ketika anak diasuh secara tidak sesuai dengan semestinya, ini akan berakibat pada perkembangan kognitif peserta didik, bahkan pada perkembangan mental anak tersebut. Lingkungan pun sangat berpengaruh pada perkembangan kognitif, semakin buruk lingkungan maupun pergaulan seseorang maka kemungkinan pengaruh lingkungan pada perkembangan kognitif peserta didik semakin besar.

\section{DAFTAR PUSTAKA}

Arief, Darnis dan Khairanis. Perkembangan dan Belajar Peserta Didik . Padang: DIP Universitas Negeri Padang, 2000

Departemen Agama RI. Al-qur'an dan Terjemahnya. Bandung: Mizan, 2009

Desmita. Psikologi Perkembangan Peserta Didik. Batu sangkar:PT Remaja Rosdakarya, 2009 
Dian.blogspot.com.2012/05/karya-tulis-ilimiah-stimulasi-anak-usia.html, Diakses 8 Agustus 2020

Djamarah, Syaiful Bahri. Guru dan Anak Didik dalam Interaksi Edukatif. Jakarta: Rineka Cipta, 2000

Gunarsa, Singgih D. Psikologi Untuk Keluarga. Jakarta: BPK. Gunung Mulia, 1979

Hasan, Chalidjah. Dimendi-Dimensi Pendidikan. Surabaya : Al-Ikhlas, 2013

Hasan, Purwakania. Psikologi Perkembangan Islam. Jakarta:PT Raja Grafindo Persada, 2006

http://alenmarlissmpn1 gresik.wordpress.com/2009/12/29/hak-dan-kewajibanpeserta-didik- berdasarkan-uu-no-20-th-2003/, Diakses 8 Agustus 2020

http://asyamforex.blogspot.com/2013/12/makalah-perkembangan-kognitifpeserta.html, Diakses 8 Agustus 2020

http://kustiawati.blogspot.com/2009/04/faktor-faktor-penunjangperkembangan.html, Diakses 8 Agustus 2020

http://teni-setiani.blogspot.com/2010/06/teori-perkembangan-kognitif.html, Diakses 8 Agustus 2020

Mujid, Abd. Psikologi Agama (Jakarta: Kalam Mulia, 2004

Muslam. Pengembangan Kurikulum PAI. Semarang: PKPI2, 2008

Mustaqim. Psikologi Pendidikan. Yogyakarta: Pustaka Pelajar, 2001

Ramayulis. Ilmu Pendidikan Islam. Jakarta: Kalam Mulia, 2008

Roqib, Moh. Ilmu pendidikan Islam. Yogyakarta: LkiS Yogyakarta, 2009

Suparno dan A. Suhaenah. Membangun Kompetensi Belajar. Jakarta: Direktorat Jendral Pendidikan Tinggi, 2001

Taufik K. Oyan D. dan Cikka, Hairuddin. Penerapan Pendidikan Dasar Militer (Diksarmil) dalam Membentuk Kepribadian Resimen Mahasiswa Institut Agama Islam Negeri (IAIN) Palu, Moderasi: Jurnal Studi Ilmu Pengetahuan Sosial, Volume 1, No. 1, 120

Syah, Muhabbin. Psikologi Pendidikan. Bandung: Remaja Rosda Karya, 1995 
Ibrahim Ismail, Perkembangan Kemampuan ... 281

Uhbiyati, Nur. Ilmu Pendidikan Islam (IPI) Untuk IAIN, STAIN, PTAIS. Bandung: Pustaka Setia, 1998

Yusuf, Syamsul. Psikologi Perkembangan Anak Dan Remaja. Bandung:PT Remaja Rosdakarya， 2012 